Acta vet. scand. $1969,10,118-126$.

From the Department of Medicine, Veterinary College of Norway, Oslo.

\title{
STUDIES ON ELECTROPHORESIS \\ ON CELLULOSE ACETATE MEMBRANE \\ OF BOVINE SERUM PROTEINS \\ IN HEALTHY ANIMALS
}

By

Nils Ek

Electrophoresis on cellulose acetate membrane was introduced by Kohn (1957). The system appears to have certain advantages over filter paper electrophoresis, especially for routine work. Separations take place relatively rapidly in this medium thereby reducing the running time considerably. Protein bands are generally sharp and well defined on these membranes and, as there is little absorption of stain by the membrane, washing requires little time. The membranes can be made completely transparent and are therefore suitable for automatic "scanning".

Different species of animals do not show the same serum protein pattern by electrophoresis. It is obvious from the literature that writers often classify the peaks of the different fractions by comparing the curves obtained with corresponding curves from other species of animals.

Several authors have mentioned problems in achieving a clearly defined separation of the different fractions in bovine serum by paper electrophoresis. Labouche (1962) found that $\beta$-globulin was not clearly separated from $\gamma$-globulin. Irfan (1967) discovered a certain component of the $\gamma$-globulin very close to the $\beta$-globulin.

In the present report, experiments for the identification of bovine serum fractions and suggestions for the improvement of the method are presented. 
The purpose of the last part of the experiment was to obtain values concerning the relative percentages of the main serum protein fractions in healthy cows by using the presented method.

\section{EXPERIMENT I}

\section{Material and methods}

Undiluted serum from healthy cows, age $>2 \frac{1}{2}$ years, was used. Pure preparations:

1. $\gamma$-globulin separated from bovine serum as described by Baumstark et al. (1964).

2. Antitrombin III purified from bovine plasma by chromatography (Abildgaard 1968a), molecular weight 64,000. By paper filter electrophoresis the motility was found to be between $\alpha_{2}$-globulin and $\beta$-globulin (Abildgaard 1968b).

\section{Electrophoresis}

A Beckman Model R Microzone Electrophoresis System with Microzone Cell Model R-101 (Anon. 1965) was used.

Buffer system:

Standard buffer B-2, Veronal.

Modified buffer with the following content:

$1.84 \mathrm{~g}$ diethylbarbituric acid

10.30 g sodium diethyl barbiturate

$0.38 \mathrm{~g}$ calcium acetate

Aqua dest. ad $1000 \mathrm{ml}$

$\mathrm{pH}: 8.6$

Eight samples of $0.25 \mu \mathrm{l}$ of serum were applied with an applicator to Microzone membranes in the last application groove. After a run of $20 \mathrm{~min}$. in the cell with a constant voltage of $250 \mathrm{v}$, the membrane was removed and stained in bromphenol blue $1 \%$ for 10 min., rinsed three times in $5 \%$ acetic acid, rinsed $1 \mathrm{~min}$. in $96 \%$ alcohol and cleared for $1 \mathrm{~min}$. in $27 \%$ acetic acid in $96 \%$ alcohol. The membrane was then placed in a drying oven at $110^{\circ} \mathrm{C}$ for $15 \mathrm{~min}$. The dried, clear membrane was scanned in an Analytrol Model R.B. and the results calculated as described in the Instruction Manual (Anon. 1957).

The electrophoresis was run under different conditions by changing the following factors: Ionic strength and composition of the buffer, voltage, running time, volume of serum applied and position of the application line. 


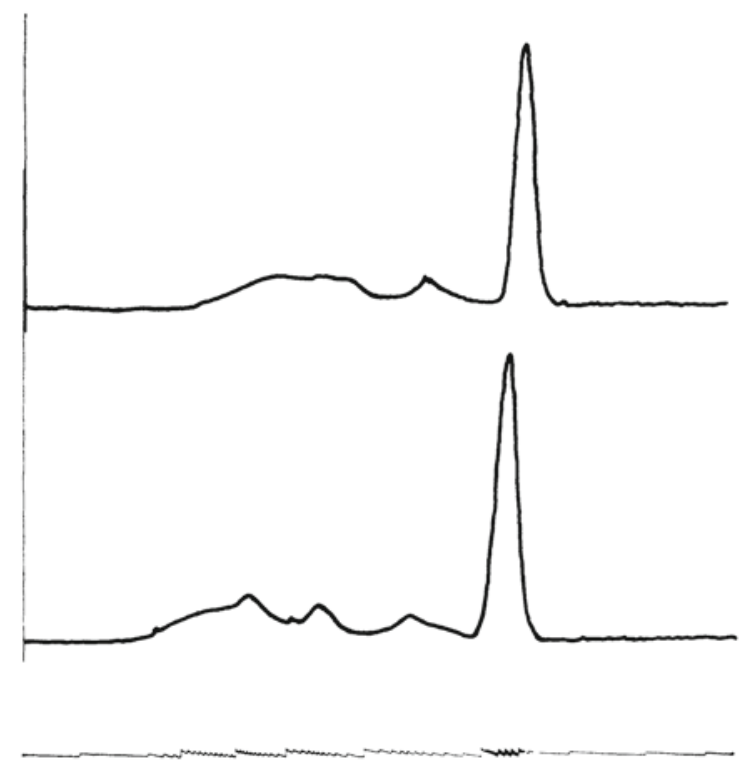

Figure 1. Electrophoresis curves of bovine normal serum with standard veronal buffer above and modified buffer below.

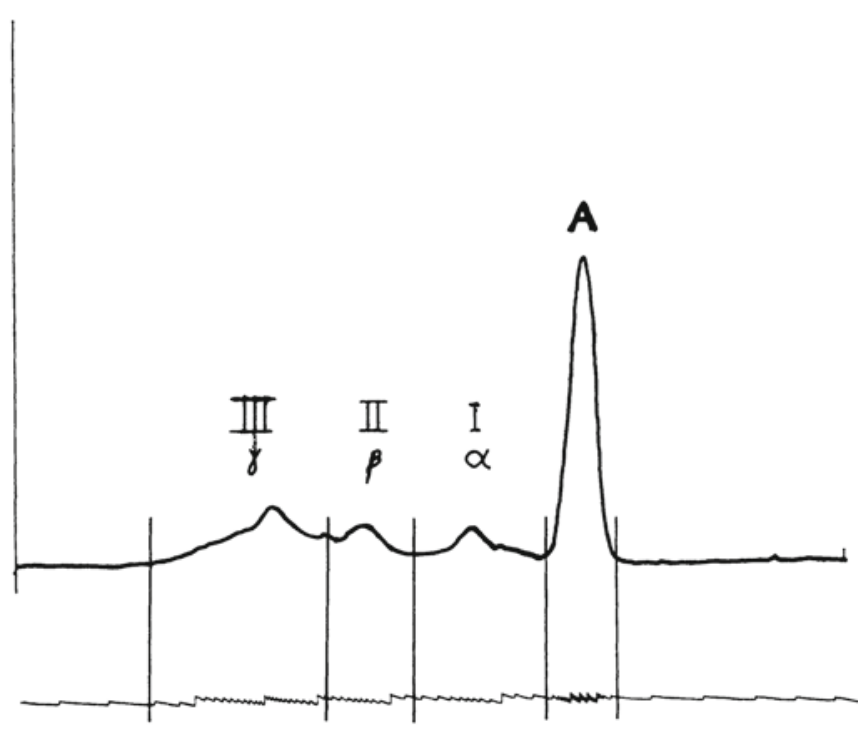

Figure 2. Electrophoresis curve of bovine serum with division of the different main fractions of serum proteins. 


\section{Results}

It was obvious that the change in voltage, running time, volume of the serum applied and the position of the application line in relation to the standard method did not produce a better separation. On the other hand, the use of a more diluted veronal buffer containing Ca-ions increased the separation. By adding calcium to the veronal buffer $\mathrm{pH}$ 8.6 Laurell et al. (1956) produced increased separation between $\beta$ - and $\gamma$-globulins.

Fig. 1 shows the curve where the serum is run with each of the two buffers, the standard buffer above and the modified buffer below. This modified buffer was used in the experiments described in the present report.

The curve produced by electrophoresis of normal bovine serum is shown in Fig. 2. The different main fractions are bounded by vertical lines. Albumin is marked $A$ and the three fractions in the globulin part I, II and III.

The separated $\gamma$-globulin and serum, run parallel, are shown in the diagram in Fig. 3. It is evident from the diagram that the $\gamma$-globulin lies in a zone corresponding to fraction III in Fig. 2. The separated globulin must be assumed to represent both the rapidly and more slowly moving sub-fractions of $\gamma$-globulin

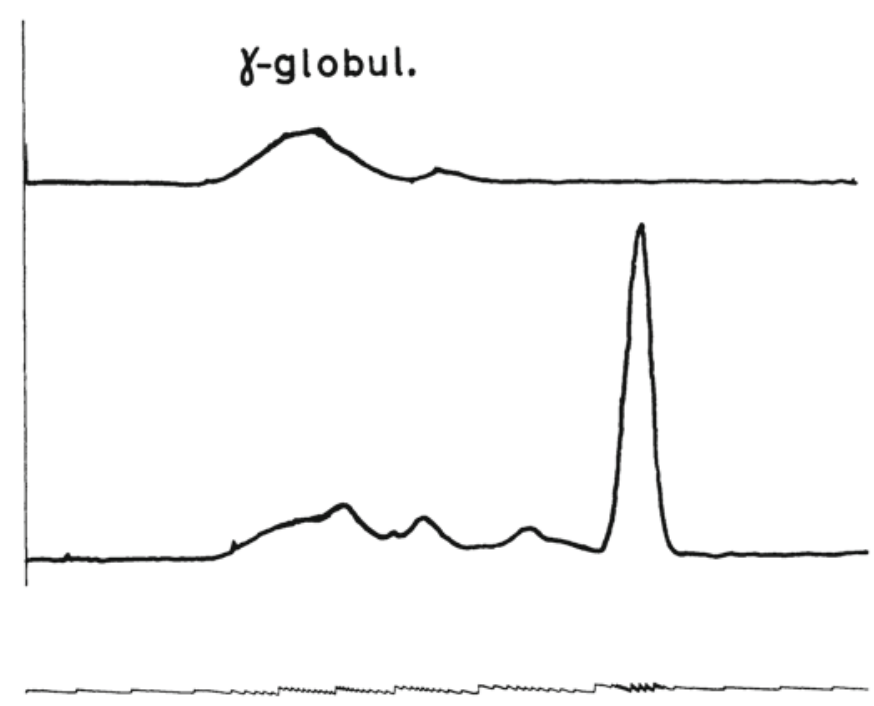

Figure 3. Parallel electrophoresis of separated bovine $\gamma$-globulin and bovine serum. 


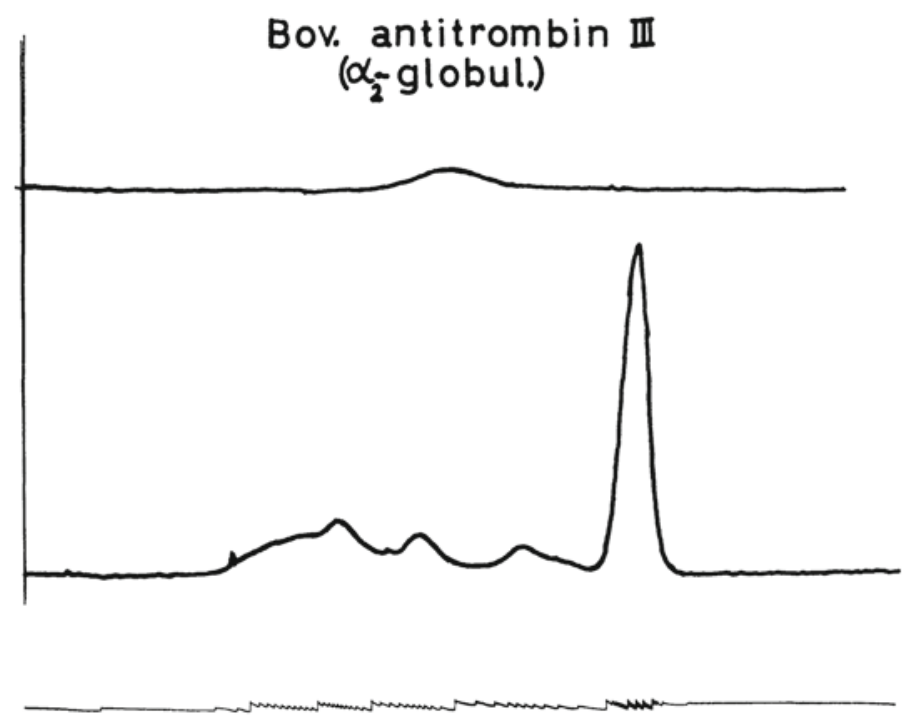

F i g u r e 4. Parallel electrophoresis of bovine $\alpha_{2}$-antitrombin III and bovine serum.

(Baumstark et al.). The small peak on the curve of the separated $\gamma$-globulin is presumed to be a trace of $\beta$-globulin. A similar phenomenon is also described by Baumstark et al. This finding led to the conclusion that fraction III is identical with the $\gamma$-globulin fraction.

In the same way, $\alpha$-antitrombin III run side by side with serum is shown in Fig. 4. As can be seen from the diagram the peak on this curve lies between fractions I and II. This probably indicates that fraction I corresponds to $\alpha$-globulin and fraction II to $\beta$-globulin.

Fig. 2 shows that $\alpha$-globulin is migrating as a broad, well defined zone. A separate small fraction was detected in some samples in the boundary close to the albumin without distinct division. $\beta$-globulin appears in a well defined zone, but in some samples a trace of division can be detected as a small additional peak in the boundary near the $\gamma$-fraction. Vesselinovitch (1959) found that in pregnant cows $\beta$-globulin was divided into two fractions as the pregnancy progressed.

The $\gamma$-globulin in the diagram forms a wide zone with a large component lying as a peak close to the boundary of $\beta$-globulin. 


\section{EXPERIMENT II}

\section{Material and methods}

Undiluted serum from 50 healthy cows, breed N.R.F., $>2 \frac{1}{2}$ years of age, was used. The blood was taken from the jugular vein.

The same method as described in Experiment I was employed for the electrophoresis. All samples were examined twice.

\section{Results}

The results of this investigation are given in Table 1.

In no case did the results differ by more than $3 \%$ when the same tests were repeated. One detail which appeared to be especially important in order to obtain uniform values was that the pen of the Analytrol was placed exactly on line 0 of the diagram at the beginning of the procedure.

T a b l e 1. Relative percentages of serum protein fractions in healthy cows.

\begin{tabular}{lllll}
\hline $\begin{array}{l}\text { No.of } \\
\text { cows }\end{array}$ & \multicolumn{3}{c}{ Albumin } & \multicolumn{1}{c}{ Globulin } \\
\hline & & \multicolumn{1}{c}{$\alpha$} & & $\beta$ \\
\cline { 5 - 5 } & Mean value $\overline{\mathrm{x}}=47.4$ & $\overline{\mathrm{x}}=11.6$ & $\overline{\mathrm{x}}=12.1$ & $\overline{\mathrm{x}=28.9}$ \\
50 & Standard deviation $\mathrm{s}=4.5$ & $\mathrm{~s}=1.3$ & $\mathrm{~s}=1.5$ & $\mathrm{~s}=5.1$ \\
& $\overline{\mathrm{x}} \pm 2 \mathrm{~s}=47.4 \pm 9.0$ & $\overline{\mathrm{x}} \pm 2 \mathrm{~s}=$ & $\overline{\mathrm{x}} \pm 2 \mathrm{~s}=$ & $\overline{\mathrm{x}} \pm 2 \mathrm{~s}=$ \\
& & $11.6 \pm 2.6$ & $12.1 \pm 3$ & $28.9 \pm 10.2$ \\
\hline
\end{tabular}

\section{DISCUSSION}

When the paper electrophoresis technique was introduced in 1950 (Turba \& Enenkel 1950), in addition to albumin, one got a division of the globulin into three components which were called $\alpha$-, $\beta$ - and $\gamma$-globulin. Thanks to newer, better and more sensitive methods it has been possible to achieve a further division thereby showing that these main components are composed of several different proteins. For clinical diagnostic use, however, this main division has assumed a practical importance even if in the future one must reckon with a much finer division of the serum fractions. For the present, however, no quantitative techniques are simple enough to replace those of today capable of classifying the various serum proteins. 
In the literature there is some variation in the normal percentages of the protein fractions in bovine serum. Perk \& Lobl (1961), using paper electrophoresis, report normal values closely agreeing with those found in this study, while Vesselinovitch (1959) and Irfan (1967), using the same method, found a somewhat higher percentage for $\gamma$-globulin and a somewhat lower one for albumin.

When the method is to be used for clinical-diagnostic work, the total protein concentration should also be determined in order to interpret the percentages correctly.

The values will also be influenced by the breed, age and health etc. of the animals examined (Vesselinovitch). In the estimation of pathological conditions it is therefore important that the values obtained can be compared with normal values acquired under the same conditions from a similar animal population.

\section{ACKNOWLEDGMENT}

Antitrombin III was supplied by Dr. U. Abildgaard, Ullevål Hospital, Department IX, Oslo, who also gave valuable advice and help during the experimental work. The author owes him a great debt of gratitude.

The author would also like to thank Prof. dr. M. Brænd, at present with the Faculty of Veterinary Science, University College, Nairobi, Kenya, for his valuable advice and guidance during the experiment.

\section{REFERENCES}

Abildgaard, U.: Highly purified antithrombin III with cofactor activity prepared by disc electrophoresis. Scand. J. clin. Lab. Invest. 1968a, 21, 89-91.

Abildgaard, U.: Personal communications 1968b.

Anon.: Model R paper electrophoresis system Instruction Manual. RIM-5. Beckman Instruments, Inc., Spinco Division, Palo Alto, Calif. 1957.

Anon.: Model R-101 microzone electrophoresis cell Instruction Manual. RM-IM-3. Beckman Instruments, Inc., 2500 Harbor Blvd., Fullerton, Calif. 1965.

Baumstark, J. S., R. J. Laffin \& W. A. Bardawil: A preparative method for the separation of $7 \mathrm{~S}$ gamma globulin from human serum. Arch. Biochem. 1964, 108, 514-522.

Irfan, $M .:$ The electrophoretic pattern of serum proteins in normal animals. Res. vet. Sci. 1967, 8, 137-142.

Kohn, J.: A cellulose acetate supporting medium for zone electrophoresis. Clin. chim. Acta 1957, 2, 297-303. 
Labouche, C.: Calcue d'erreurs dans l'interprétation quantitative des électrophorèses de sérum des bovidés domestiques. (Calculation of errors in the quantitative interpretation of electrophoresis of the serum of domestic bovines). Ann. Biol. anim. 1962, 2, $251-263$.

Laurell, C. B., G. Laurell \& N. Skoog: Buffercomposition in paper electrophoresis. Considerations on its influence, with special reference to the interaction between small ions and proteins. Clin. Chem. 1956, 2, 99-111.

Perk, K. \& K. Lobl: Chemical and electrophoretic studies of the serums of cattle infected naturally with Asia-1 type Foot-and-Mouth disease virus. Amer. J. vet. Res. 1961, 22, 217-223.

Turba, F. \& H. J. Enenkel: Electrophoresis in filter paper. Naturwissenschaften 1950, 37, 93-99.

Vesselinovitch, S. D.: The analysis of serum proteins of domestic animals by filter-paper electrophoresis. A review. Cornell Vet. $1959,49,82-96$.

\section{SUMMARY}

A method for rapid electrophoresis of serum proteins on a cellulose acetate membrane is described.

In order to experimentally identify the various larger globulin fractions in normal bovine serum, pure bovine $\gamma$-globulin and a bovine $\alpha_{2}$-fraction (Antitrombin III) were used.

These fractions were electrophoretically compared with bovine serum and the various fractions on the diagram determined.

A diluted veronal buffer with added Ca-acetate gave considerably better separation than the reported standard buffer.

In the last part of the experiment normal percentage values for the composition of the protein fractions in bovine serum were calculated by the method described. The material consisted of 50 cows of the N.R.F. breed. The values are compared with corresponding figures reported by other authors, and the results are discussed.

\section{ZUSAMMENFASSUNG \\ Studien über Zellulose-Azetat-Elektrophorese der bovinen Serum- proteine von normalen Tieren.}

Eine Methode zur Schnellelektrophorese von Serumproteinen auf Zellulose-Azetat-Membran wird beschrieben.

Um die einzelnen grösseren Globulinfraktionen in bovinem Normalserum experimentell zu identifizieren, wurde reines bovines $\gamma$-Globulin und eine bovine $\alpha_{2}$-Fraktion (Antitrombin III) benutzt.

Diese Fraktionen wurden elektrophoretisch mit bovinem Serum verglichen und die einzelnen Fraktionen im Diagramm wurden lokalisiert.

Ein verdünnter Veronalpuffer dem Ca-Azetat zugesetzt war gab eine bedeutend bessere Separation als der empfohlene Standardpuffer. 
Im letzten Teil des Versuches wurden die Normalwerte der prozentualen Zusammensetzung der Proteinfraktionen in bovinem Serum mit Hilfe der beschriebenen Methode berechnet. Das Material bestand aus 50 Kühen der NRF-Rasse. Die Werte werden mit entsprechenden Zahlen, die von anderen Verfassern angegeben sind, verglichen und die Ergebnisse werden diskutiert.

\section{SAMMENDRAG}

Studier over elektroforese av bovine serumproteiner fra normale dyr på cellulose acetat membran.

Det omtales en metode til hurtigelektroforese av serumproteiner på cellulose acetat membran.

For eksperimentelt å identifisere de enkelte grøvre globulinfraksjoner i bovint normalserum, ble anvendt rent bovint $\gamma$-globulin og en bovin $\alpha_{2}$-fraksjon (Antitrombin III).

Disse fraksjoner ble elektroforetisk sammenlignet med bovint serum og de enkelte fraksjoner på diagrammet fastlagt.

En fortynnet veronalbuffer tilsatt Ca-acetat ga betydelig bedre separasjon enn den angitte standardbuffer.

I siste del av fors $\varnothing$ ket ble det beregnet normalverdier vedr $\varnothing$ rende den prosentvise sammensetning av proteinfraksjonene i bovint serum med den beskrevne metodikk. Materialet besto av $50 \mathrm{kyr}$ av N.R.F.rasen. Verdiene ble sammenlignet med tilsvarende tall angitt av andre forfattere og resultatene diskutert. 